\title{
TROTTA, MARIANA DE ROSA. O DISCURSO DA DANÇA: UMA PERSPECTIVA SEMIÓTICA. CURITIBA, CRV, 2011.
}

Caroline Konzen Castro*

A semiótica está ganhando cada vez mais notoriedade como ferramenta para a análise dos discursos artísticos. Principalmente na área da dança ela tem se destacado como uma fundamentação teórica para se analisar espetáculos desta arte sincrética. Sob esta perspectiva, de uma análise semiótica do discurso da dança, Mariana de Rosa Trotta desenvolve o livro $O$ discurso da dança: uma perspectiva semiótica. A autora é professora adjunta do Departamento de Arte Corporal da UFRJ, além de ser pesquisadora em linguística, com ênfase em semiótica da dança.

A obra O discurso da dança: uma perspectiva semiótica é resultado da dissertação de mestrado de Mariana de Rosa Trotta.
* carolinekonzen@yahoo.com.br

Mestranda do Programa de Pós-Graduação em

Estudos de Linguagens do Centro Federal de Educação Tecnológica de Minas Gerais (POSLING-CEFET-MG).

A autora justifica a escolha da dança por ser uma arte pouco estudada dentro da academia e pelos pesquisadores. Também pelo fato de o discurso da dança ser expresso sincreticamente, ou seja, em um espetáculo de dança, por exemplo, há a manifestação de diversas linguagens artísticas como a música, o gestual, o cenário e o figurino. Dessa forma, são diversificados os recursos utilizados para se construir o sentido da obra.

O livro, publicado pela editora CRV, possui 118 páginas distribuídas em: uma introdução, cinco capítulos, uma conclusão e vinte e cinco depoimentos em anexo.O objetivo central da obra é definir os parâmetros de uma análise semiótica da dança ou a construção de uma gramática semiótica da 
dança.Para isso foi examinado os procedimentos de construção dos sentidos na dança, ou seja, suas relações entre o plano do conteúdo e o plano da expressão; as características da dança clássica e da dança moderna; a intertextualidade e a interdiscursividade como parte do sentido da obra.

A introdução discursa sobre a perspectiva teórica e a metodologia utilizada pela autora,baseadasna semiótica discursiva de linha francesa (semiótica Greimasiana). Esta escolha se deu, segundo a autora, devido aos bons trabalhos com o plano do conteúdo e da expressão desenvolvidos no decorre das investigações científicas. Além de ser uma teoria adequada e coerente para uma análise do discurso artístico. O ponto de partida para o estudo foi um texto clássico de Greimas, publicado em 1968, Condiciones de una semiótica del mundo natural, que trabalha a questão da gestualidade.Os objetos de análise da obra, que serviram como via de acesso para se construir uma gramática semiótica da dança e apontar as características específicas da dança clássica e da dança moderna, foram dois espetáculos de dança: o Ballet Cinderella de Panov (dança clássica) e o Ballet Cendrillon, de Maguy Marin (dança moderna). Os critérios da escolha, pela autora destes espetáculos foi o fato de contarem a mesma história, embora um ser expresso nas características específicas da dança clássica e o outro ser expresso nas características da dança moderna.
O primeiro capítulo, intitulado A Semiótica Visual e a Semiótica da Dança, expõealguns parâmetros teóricos sobre a gestualidade, com base na semiótica greimasiana. O intuito é observar como a gestualidade acontece na dança. Em primeiro lugar a autora expõe que para a gestualidade criar sentido para o homem é preciso existir um eixo de comunicação entre um remetente e um destinatário. Esta relação na semiótica é vista como um contrato de comunicação, ou contrato fiduciário. No caso do espetáculo de dança, o contrato fiduciário é definido pelo desejo de determinado coreógrafofazer-parecido e fazer-crer através da persuasão. Por exemplo, no renomado balé $O$ Lago dos Cisnes, o reconhecimento pelo público da figura do cisne nas formas corporais dançadas pela bailarina se refere ao fazer-persuasivo do coreógrafo. Neste caso, o coreógrafo (remetente) propõe um contrato com o público (destinatário) fazendo com que o público reconheça a figura do mundo, cisne em uma bailarina, através da persuasão. A autora também cita o renomado ballet Bolero de Ravel, do coreógrafo Béjart, como um caso em que o coreógrafo desejou dificultar o processo de reconhecimento pelo público de figuras do mundo, tratando prioritariamente de sentimentos.

O segundo capítulo, denominado Dialogismo das Sapatilhas, objetiva estabelecer o diálogo entre a dança clássica e a dança moderna a partir do discurso bivocal representado por duas 
categorias teóricas: a polêmica aberta e a polêmica velada desenvolvidas por Bakhtin. Para isso a autora selecionou discursos publicados tanto de coreógrafos e críticos de dança clássica como de coreógrafos e críticos dedança moderna. De acordo com a autora, a polêmica aberta está orientada para o discurso refutável do outro. Isso é percebido nos depoimentos, em que cada estilo de dança em análise, o clássico e o moderno, busca definir a sua arte de acordo com as suas propostas estéticas. Tanto a dança clássica quanto a dança moderna ressemantizam a práxis gestual (gesticulação aprendida e tornada automática), porém o grau de ressemantização do movimento na dança clássica é maior do que o grau de ressemantização do movimento na dança moderna, pois nesta há um reconhecimento maior da práxis gestual do que na dança clássica. Devido a este reconhecimento mais evidente da práxis gestual na dança moderna ela se aproxima mais do público do que a dança clássica, no que se refere à gestualidade. No entanto, em relação à forma como a narrativa é contada, em cada um destes estilos, a dança clássica se aproxima mais do público do que a dança moderna, uma vez que a narrativa é linear e mais conhecida pelo público, como os contos de fada. Na polêmica velada o discurso do coreógrafo moderno está orientado para o seu objeto, ou seja, qualquer afirmação sobre o objeto pode atacar polemicamente o discurso da dança clássica ou vice e versa. Para analisar como se dá a polêmica velada entre a dança clássica e a dança moderna a autora fez um estudo do plano da expressão de ambas e relacionou as categorias do plano da expressão com as categorias do plano do conteúdo. Assim foram apontadas diferenças em relação à postura corporal, ao posicionamento do conjunto de bailarinos em cena, a estabilidade do corpo, a gestualidade dos pés, das mãos, dos braços e da cabeça.

O capítulo intitulado Análise de um espetáculo clássico: a "Cinderella" de Panové o terceiro na obra de Mariana Trotta. Neste capítulo, a autora analisa o vídeo do balé Cinderella, de Panov, que é interpretada pelo "Ballet of Ashdod" e encenado na Ópera de Berlin. Ela analisa o plano do conteúdo, desde o nível das estruturas narrativas e discursivas até o nível das estruturas fundamentais. Em seguida há a análise do plano da expressão e por fim são definidas as relações que se estabelecem entre as categorias da expressão e as categorias do conteúdo.

O quarto capítulo, Análise de um espetáculo moderno: a "Cendrillon" de brinquedo, examina o espetáculo de dança moderna Cendrillon, de Maguy Marin, interpretado pelo Lyon Opera Ballet. Os mecanismos de análise deste espetáculo foram os mesmos dos realizados no capítulo três.

O último capítulo, denominado O Diálogo das Cinderelas, relaciona as análises realizadas nos capítulos anteriores de forma a enxergarmos as principais diferenças ou, semioticamente, as 
quatro grandes oposições entre elas. Por fim, ao chegarmos à conclusão é possível refletir sobre as relações semióticas entre a dança clássica e a dança moderna e sobre como a semiótica é produtiva e eficaz como ferramenta de análise do discurso da dança. Julgo, portanto, que o livro é de leitura indispensável para quem deseja se aventurar tanto na magia da arte da dança quanto na sedução da ciência da semiótica e, principalmente, nas tramas de relações entre a semiótica e a dança. 